\title{
Factors Influencing Teacher Professionalism Development on Secondary School
}

\section{Anisa Lutfiyana and Sugito \\ Postgraduate Program, Yogyakarta State University}

\section{Abstract}

Development is a permanent issue in school worldwide which teacher demand in enhance their competence, especially in professionalism competence. The main purpose of this article is to investigate whether three factors were influence teacher professionalism development, those are (1) leadership of principal, (2) organizational commitment, (3) school culture. This research is survey research. The population was 182 teachers of Muhammadiyah Secondary School of Yogyakarta. A sample of 162 teachers was established using the simple random sampling technique. The data were collected through questionnaire that had been tested for validity and reliability. The data analysis technique used double regression. The research finding shows that there was a positive and significant effect of: (1) leadership of principal on teacher professionalism development, as much $15,7 \%$, (2) organizational commitment on teacher professionalism development, as much $15,7 \%$, (3) school culture on teacher professionalism development, as much $21,1 \%$.

Keywords: Professionalism Development, Effective Leadership, Organizational Commitment, School Culture.

\section{Introduction}

and redistribution provided that

the original author and source are credited.

Selection and Peer-review under the responsibility of the ICMEd Conference Committee.

Education in the century of knowledge demands modern and professional education. Educational institutions are expected to produce effective results with leadership, staff, teaching and learning, staff development, curriculum, goals and expectations, school climate, personal communication, community and parents. Education also has a strategic role for young people who have high intelligence and sophistication. It is then the responsibility of every educator to provide an appropriate educational program in support of the development of learning and learning objectives. Student development depends on the quality that students experience in school [1]. The quality of teaching reflects the quality of teachers. In other words the better the quality of teacher, the higher students' learning achievement. 
One of the facilities obtained by teachers in the 21st century is certification and license, in which almost all educators or teachers in Indonesia have been certified and licensed. It is just for improve teacher professionalism and answers any demand that are the quality of educational graduates. In this case the teacher becomes an absolute requirement in the success of education. Therefore, the government keeps on pursuing programs or activities in order to improve the quality of human resources or teachers. One of the governments' efforts to improve the quality of teachers is the existence of teacher professional development program or so-called Continuous Professional Development (Permenneg PAN and RB, 16/2009). Elements of professional development activities include: self-development, scientific publications, and innovative work.

Facts in the field show the tendency of teachers very rarely develop themselves in making scientific publications and innovative works. The news showed that there are about 800,000 teachers cannot make scientific papers. During their personal experience in giving teachers a workshop of action research, they observed that the participating teachers seemed to lack good understanding of a variety of research methodologies, not to mention that of classroom action research, which is a close part of their teaching profession [2]. Teachers still have difficulty in determining what research methods should be used to solve the problems faced in the classroom. In addition, teachers also have difficulty preparing a good research proposal in accordance with the rules or the format of a proposal or linguistic rules appropriate. In the making of scientific papers or writing a proposal of class action research required a great motivation for both the teachers themselves and institutions, but the reality shows some teachers Muhammadiyah still hampered the problem.

In responding to this conditions would need to be sought for some factors influence teacher professionalism development. In this study focus on three factors, those are effective leadership, organizational culture, and teacher commitment. Whether those three factors influence on teacher professionalism or not.

\section{Literature Review}

\subsection{Professionalism development}

Teacher professionalism development is studied and presented in the relevant literature in many different ways. Professional development is defined as processes and activities designed to improve the professional knowledge, skills, and attitudes of teachers in 
improving student learning Guskey [3], Darling-Hammond L. et al [4], Gebreselassie [5]. Permenneg PAN and RB number 16 of 2009, reads sustainable profession development activities including: self-development, scientific publications, and innovative works. Selfdevelopment is an effort made by a teacher in order to improve their professionalism. This self-development activity is intended to enable teachers to achieve and/or improve teacher competence which includes: pedagogical, personality, social, and professional competence as mandated in Law Number 20 Year 2003 on National Education System. Thus the teacher is expected to eventually be able to carry out their main duties and obligations in learning/mentoring, as well as in carrying out additional tasks relevant to the school function in a professional manner.

\subsection{Effective leadership}

School leaders have an important role in staff and teachers' development in schools. The result study of Gumus \& Kemal [6], Holland [7], Combe [8], Emmanouil [9], Kose [10], Mahdy [11] shows that there is influences between effective leadership toward teacher professionalism development. It means that principals play a significant role in teacher professional development. The major role of school principals in the area of teacher professional development is to grow teacher confident, improve their learning capability and build leadership capacity among staff and teacher in their schools. Thus the good learning community will be done and student academic achievement can be increase. Professional teachers need professional leaders and leadership [12]. Therefore, the leadership of the principal will encourage the development of the behavior of the individual he or she leads to the desired change.

\subsection{Organizational commitment}

Organizational commitment is seriousness of teachers in carrying out their job duties as a teacher and educator. Organizational commitment can lead to positive behavior toward work organization in the form of affective commitment, continuance commitment, and normative commitment [12]. The result study of Riley [13], Noordin [14], Ibrahim [15], Mannan [16], shows that there is strong relationship between Organizational commitment and teacher professionalism development. It means that teacher with the good commitment can accept easily a new knowledge and advice from principle or colleague. Motivation from inside of teacher also can build itself to improve their capability in teaching learning continuously. Thus, teacher commitment is one of important thing 
that can influence teacher professionalism development and high commitment of a teacher will be more responsible for teacher work, so that will have an impact on the success of school goals.

\subsection{School culture}

School organizational culture is the values, norms, beliefs, assumptions, mindsets that underlie the behavior of educators or education personnel in performing their duties. Rauf et al, 2012 stated that when teachers view their school culture as positive, they tend to have a positive attitude toward professional development in schools. Therefore, a school with a positive culture will provide an atmosphere of a fun school environment that will make the school community both teachers, as well as students feel comfortable and safe in school. Yusof [18] argue that teachers can work well with high school culture. One example of a positive or high culture is a culture of cooperation and mutual trust, whether a teacher colleague or with a principal. The development of education and learning can be achieved. In other words, the school will support the improvement of teachers 'creativity in learning, as well as colleagues' friends will support each other and motivate each other by way of a discussion about the new science gained. Indirectly teachers will maximize their teaching skills in the classroom. Peterson \& Deal [17] also describes a school with a strong positive culture when its staff has a common goal and is fully committed to its task. This will indirectly affect teacher and staff development. Teachers will have the spirit and high motivation in improving their teaching skills either through from activities held by the school which later will impact on student achievement.

\section{Material \& Methodology}

This research is survey research with quantitative technique. The population was teacher of Muhammadiyah Secondary School of Yogyakarta. A sample of 162 teachers was established using the simple random sampling technique. The data were collected through questionnaire that had been tested for validity and reliability. The data analysis technique used double regression.

\section{Results and Discussion}




\subsection{Result}

The testing of the hypothesis in the study aims to prove the impact of the principal's leadership, organizational commitment, and school culture on teacher professionalism development of Muhammadiyah secondary school of Yogyakarta. Data analysis used multiple regression. In table 1, a summary of the results of multiple regression analysis will be discussed using the SPSS 22 for Windows program.

TABLE 1: Results of Regression Analysis of Principal Leadership $\left(x^{1}\right)$, Organizational Commitment $\left(x^{2}\right)$, and School Culture $\left(x^{3}\right)$ on Teacher Professionalism Development $(Y)$.

\begin{tabular}{l|c|c|c|c|} 
Variable & $\begin{array}{c}\text { Regression } \\
\text { Coefficient (b) }\end{array}$ & $\mathbf{T}_{\text {Count }}$ & Sig. & Conclusion \\
\hline Principal Leadership & 0.157 & 2.224 & 0.028 & significance \\
\hline $\begin{array}{l}\text { Organizational } \\
\text { Commitment }\end{array}$ & 0.157 & 2.329 & 0,021 & significance \\
\hline School Culture & 0.211 & 2.582 & 0,011 & significance \\
\hline Constanta = -1.062 & & & & \\
\hline $\mathrm{R}^{2}=0.22$ & & & & \\
\hline $\mathrm{F}_{\text {Count }}=12.455$ & & &
\end{tabular}

Source: Primer Data 2018

\subsection{Discussion}

\subsubsection{The impact of principle' leadership on teacher professionalism development}

The results of this study indicate that there is a positive and significant influence of the principal's leadership on the development of the teacher's professionalism in the city of Yogyakarta. This can be shown from the previous calculation, where the value of t count is 4.318 with a significant level of 0.00 smaller than 0.05 and the regression coefficient has a positive value of 0,157 . This shows that the development of the professionalism of teachers in Yogyakarta's Muhammadiyah Middle School 15,7\% is determined by the principal's leadership variable. Thus it can be concluded that this study succeeded in proving the first hypothesis, namely "There is a positive and significant influence of the principal's leadership on the development of teacher professionalism". 


\subsubsection{The impact of organizational commitment on teacher profession- alism development}

The results of this study indicate that there is a positive and significant influence of organizational commitment on the development of teacher professionalism in the city of Yogyakarta. This can be shown from the previous calculation, where the value of $t$ count is 4,434 with a significant level of 0.00 smaller than 0.05 and the regression coefficient has a positive value of 0.157 . This shows that the development of the professionalism of teachers in Yogyakarta's Muhammadiyah Middle School 15,7\% is determined by the variable organizational commitment. Thus it can be concluded that this study succeeded in proving the second hypothesis, namely "There is a positive and significant influence of organizational commitment to the development of teacher professionalism".

\subsubsection{The impact of school culture on teacher professionalism develop- ment}

The results of this study indicate that there is a positive and significant influence of organizational organizational culture on the development of teacher professionalism in the city of Yogyakarta. This can be shown from the previous calculation, where the value of count is 4,676 with a significant level of 0.00 smaller than 0.05 and the regression coefficient has a positive value of 0.211 . Thus it can be concluded that this study succeeded in proving the third hypothesis, namely "There is a positive and significant influence of school organizational culture on the development of teacher professionalism".

\section{Conclusion}

Based on data analysis and discussion, conclusions can be taken as follows:

1. There is a positive and significant influence of the principal's leadership on the teacher professionalism development in Muhammadiyah Secondary School of Yogyakarta, which is equal to $15.7 \%$ with a significance value of $0.028<0.05$.

2. There is a positive and significant influence of organizational commitment on the teacher professionalism development in Muhammadiyah Secondary School of Yogyakarta, which is equal to $15.7 \%$ with a significance value of $0.021<0.05$. 
3. There is a positive and significant influence of school organizational culture on the teacher professionalism development in Muhammadiyah Secondary School of Yogyakarta, which is equal to $21,1 \%$ with a significance value of $0.011<0.05$.

This study underlines that the principal can build a positive and supportive school culture. Principal support by applying shared vision and responsibilities, can develop teachers' organizational commitment to contribute to positive culture in schools. Therefore, with the motivation and support from the school principal, the commitment of teachers in their work, as well as high school culture will create a superior school that will continuously support all teacher professional development activities both held by schools or out of school, so the purpose of school and competent graduates can be achieved.

\section{References}

[1] Joyce \& Shower. "Improving Inserving Training: The Messages of Reaseach," The Association for Supervision and Curriculum Development, (1980).

[2] Kholid N.M. \& Masduki. "Pengembangan Kemampuan Penelitian dan Penulisan Karya Ilmiah Bagi Guru Matematika Sma/Smk Muhammadiyah Di Klaten dan Sukoharjo," 2549-5631, (2017).

[3] Guskey, T.R. "Professional Development and Teacher Change," Teachers and Teaching: Theory and Practice, 8 (3/4), 381-389, (2002).

[4] Darling, H. L., Maria E. H., \& Madelyn G. "Effective teacher professional development. Palo Alto," CA: Learning Policy Institute, (2017).

[5] Gebreselassie M. 'Principals' Roles in Fostering Teachers' Continuous Professional Development in Government Secondary Schools of Addis Ababa," Ethiopia, (2015).

[6] Gumus, S. and Kemal, M. "The Effects of Teacher and School-Level Factors on Teachers' Participation in Professional Development Activities: The role of principal leadership", Journal of International Education Research, Fourth Quarter 9(4), (2013).

[7] Holland, P. E. "The Principal's Role in Teacher Development", Srate Journal, 17(1), (2009).

[8] Combee, S. The Relationship Between Administrative and Teacher Efficacy in The Professional Life of Special Education Teachers", Theses and Dissertation from Virginia Commonwealt University, (2014). 
[9] Emmanouil, K, Anasstasiou O., \& Loukeri P. I. “The Impact of Leadership on Teachers' Effectiveness", Internasional Journal of Humanities and Social Science. Vol. 4, No. 7(1), (2014).

[10] Kose. B. W. "The Principals Role in Professional Development for Socal Justice", Articles Urban Education. 44 (6), (2009).

[11] Mahdy, N. H. "The Impact of Leadership Style on Teachers' Professional Development”, Dissertation Supervision. Dubai, (2016).

[12] Priansa. D.J. "Menjadi Kepala Sekolah dan Guru Professional”, Bandung: Pustaka Setia, (2017).

[13] Riley R., W., Marshall S., \& Pascal D., F."Teacher Professionalization and Teacher Commitment: A Multilevel Analysis", National center for Education Statistic. NCES 97-069, (1997)

[14] Noordin, F., Rashid, R. M., Ghani, R., Rasimah A., \& Darus, Z. "Teacher Professionalisation and Organisational Commitment: Evidence from Malaysia", International Business \& Economics Research Journal, 9(2), 49-52, (2010).

[15] Ibrahim, M. “Teachers' Perceptions of Professional Commitment (Affective, Continuance and Normative Commitment) to Teaching Profession". European Journal of Business and Management. 7 (1), 2222-1905, (2015).

[16] Mannan, F. “The Relationship Between Women Principal Instructional Leadership Practices, Teacher Organizational Commitment and Teacher Professional Community Practice in Secondary Schools in Kuala Lumpur", Thesis. Institute of educational leadership University of Malaya Kuala lumpur, (2017).

[17] Peterson, K. and Deal T. (2002). "How Leaders Influence the Culture of Schools. Educational Leadership", 56 (1), 2830. 